\title{
Effect of sampling effort and sampling frequency on the composition of the planktonic crustacean assemblage: a case study of the river Danube
}

\author{
Csaba Vadadi-Fülöp • \\ Levente Hufnagel · Katalin Zsuga
}

Received: 16 September 2008 / Accepted: 2 February 2009

(C) Springer Science + Business Media B.V. 2009

\begin{abstract}
Although numerous studies have focused on the seasonal dynamics of riverine zooplankton, little is known about its short-term variation. In order to examine the effects of sampling frequency and sampling effort, microcrustacean samples were collected at daily intervals between 13 June and 21 July of 2007 in a parapotamal side arm of the river Danube, Hungary. Samples were also taken at biweekly intervals from November 2006 to May 2008. After presenting the community dynamics, the effect of sampling effort was evaluated with two different methods; the minimal sample size was also estimated. We introduced a single index (potential dynamic information loss; to determine the potential loss of information when sampling frequency is reduced. The formula was calculated
\end{abstract}

C. Vadadi-Fülöp

Department of Systematic Zoology and Ecology, Eötvös Loránd University, Pázmány P. sétány 1/c, 1117 Budapest, Hungary

L. Hufnagel $(\varangle)$

Department of Mathematics and Informatics,

Corvinus University of Budapest, Villányi út 29-33,

1118 Budapest, Hungary

e-mail: leventehufnagel@gmail.com

K. Zsuga

Environmental and Water Research Institute

(VITUKI), Kvassay út 1, 1095 Budapest, Hungary for the total abundance, densities of the dominant taxa, adult/larva ratios of copepods and for two different diversity measures. Results suggest that abundances may experience notable fluctuations even within 1 week, as do diversities and adult/ larva ratios.

Keywords Sample size - Seasonal dynamics • Diversity $\cdot$ Copepoda $\cdot$ Cladocera

\section{Introduction}

One hinge of monitoring ecological communities is the sample-taking procedure, which has both some practical and theoretical aspects. When our objective is to explore temporal patterns in a given community, we have to face at least two problems: sampling effort and sampling frequency. It is conspicuous that sampling effort influences sample representativeness in some ways (Cao et al. 2002a, b; Schmera and Erōs 2006, 2008). There are also computer techniques, e.g. the bootstrap method (Efron 1979; Efron and Tibshirani 1993), which generates frequency distributions of the parameter of interest, and the sampling sufficiency is achieved when the parameter reaches stability or the required level (DePatta Pillar 1998). The importance of rare species in community analyses is also a controversial issue. Some authors have questioned the use of rare species as they 
contribute little to community dynamics and add background noise (Marchant 1999; Gauch 1982); others argued that deleting rare species can damage the sensitivity of methods (Cao et al. 1998). In the simplest case, sampling effort means designating the minimal sample size, which is considered optimal when the potential species number is maximised. In practice, the area containing most of the species of the investigated community is refered to as the constant minimal area (Balogh 1953). One useful method for determining the constant minimal area of a community is applying the constant rule of Du Rietz et al. (1920). The Du Rietz curves describe the relationship between species number and its constancy levels. Incidental species may lead to an overestimation of the species minimal area, whereas highly dominant species may lead to an underestimation of the abundance minimal area (Kronberg 1987).

When determining the sampling frequency, one should take into consideration the generation time of the investigated population, which is estimated at 3-7 days by rotifers, weeks by cladocerans and months by copepods (Naidenow 1998). Zooplankton investigations with daily frequency have been conducted poorly due to the relatively labourintensive and time-consuming work. These studies have focused on population dynamics and production of a given species (Bothár 1987; Mavuti 1994) or elucidating possible factors controlling plankton dynamics (Ferrari et al. 1985; Zagami et al. 1996; Gulyás 1987); however, little emphasis was put on the evaluation of sampling strategies (Bothár 1996). The diel vertical migration of zooplankton is well-documented (Cushing 1951; Lampert 1989; Bollens and Frost 1991; Cuker and Watson 2002), but it is based on sampling within a day, which does not contribute to our better understanding of seasonal patterns.

Although the Water Framework Directive of the European Union does not require the monitoring of zooplankton communities, it can still provide us with useful information inasmuch as zooplankton is regarded as a crucial component of aquatic ecosystems because of its abundance and its role in the trophic chain.

The present paper was aimed at examining the species composition and temporal patterns of the planktonic crustacean assemblage within a 1.5-year study with special regard to a 39-day-long period when zooplankton was sampled with daily frequency. The age, sex and productivity distributions of the most abundant species were also determined within the 39 days. Diversity patterns were analysed with various methods (diversity indices, diversity profiles). The main purpose of this study was to detect the effect of sampling effort and sampling frequency on the composition of the planktonic crustacean assemblage. The optimal sample size was defined based on two different methods. A simple index [potential dynamic information loss (PDI)] was introduced to determine the loss of information when sampling frequency is reduced.

\section{Materials and methods}

Study site

The river Danube is the second largest river in Europe and is more than $2,800 \mathrm{~km}$ long, with a catchment area of $817,000 \mathrm{~km}^{2}$. The RáckeveSoroksár Danube arm is the second largest side arm in the Hungarian section of the river Danube, and is located between 1,642 and 1,586 river kilometres. The study was conducted in the side arm of the Ráckeve-Soroksár Danube downstream of Budapest in the Sport-sziget side arm $\left(47^{\circ} 21^{\prime}\right.$ $\left.38^{\prime \prime} \mathrm{N}, 19^{\circ} 05^{\prime} 08^{\prime \prime} \mathrm{E}\right)$. The Sport-sziget side arm is a parapotamal type of water body; it is situated in the area of Dunaharaszti. The arm length is $500 \mathrm{~m}$, the width is $20-30 \mathrm{~m}$ and the depth is about $1-1.5 \mathrm{~m}$; the water level fluctuation is negligible due to regulations. In the littoral zone, macrovegetation is formed mainly by reed; the siltation is remarkable. Although the side arm has a permanent connection to the Ráckeve-Soroksár Danube, it can be regarded as stagnant water. The study site was designated on the basis of our objectives, which required a water body with abundant crustacean plankton within a river, and possibilities for daily sampling; what is more, it is entitled to major interest since the RáckeveSoroksár Danube deserves attention, owing to its utilisations and human impact. 
Table 1 Zooplankton taxa recorded in the Sport-sziget side arm

\begin{tabular}{|c|c|c|c|c|}
\hline Taxa & $\begin{array}{l}\text { Average densities } \\
\text { during the study } \\
\text { period(ind./l) }\end{array}$ & $\begin{array}{l}\text { Constancy } \\
\text { during the } \\
\text { study period }(\%)\end{array}$ & $\begin{array}{l}\text { Average densities } \\
\text { during the 39-day } \\
\text { period (ind./l) }\end{array}$ & $\begin{array}{l}\text { Constancy during } \\
\text { the } 39 \text {-day } \\
\text { period }(\%)\end{array}$ \\
\hline \multicolumn{5}{|l|}{ Cladocera } \\
\hline Acroperus harpae (Baird, 1834) & 0.03 & 1.47 & 0.05 & 2.56 \\
\hline Alona affinis (Leydig, 1860) & 0.13 & 4.41 & 0.00 & 0.00 \\
\hline Alona intermedia Sars, 1862 & 0.03 & 2.94 & 0.00 & 0.00 \\
\hline Alona quadrangularis (O. F. Müller, 1785) & 0.40 & 19.12 & 0.31 & 15.38 \\
\hline Alona rectangula Sars, 1862 & 9.79 & 82.35 & 14.08 & 100.00 \\
\hline Bosmina longirostris (O. F. Müller, 1785) & 338.06 & 85.29 & 67.97 & 97.44 \\
\hline Camptocercus rectirostris Schoedler, 1862 & 0.01 & 1.47 & 0.03 & 2.56 \\
\hline $\begin{array}{l}\text { Ceriodaphnia quadrangula } \\
\text { (O. F. Müller, 1785) }\end{array}$ & 0.62 & 4.41 & 0.00 & 0.00 \\
\hline Chydorus sphaericus (O. F. Müller, 1776) & 0.66 & 22.06 & 0.05 & 5.13 \\
\hline Daphnia sp. juvenile & 0.06 & 1.47 & 0.00 & 0.00 \\
\hline Daphnia cucullata Sars, 1862 & 0.38 & 11.76 & 0.05 & 2.56 \\
\hline Daphnia longispina O. F. Müller, 1785 & 1.34 & 7.35 & 0.26 & 2.56 \\
\hline Daphnia obtusa Kurz, 1874 & 0.32 & 1.47 & 0.00 & 0.00 \\
\hline Daphnia pulex Leydig, 1860 & 0.04 & 2.94 & 0.03 & 2.56 \\
\hline Diaphanosoma brachyurum (Liévin, 1848) & 0.62 & 7.35 & 0.62 & 10.26 \\
\hline Diaphanosoma mongolianum Uéno, 1938 & 3.63 & 54.41 & 5.00 & 79.49 \\
\hline Disparalona rostrata $($ Koch, 1841$)$ & 0.82 & 27.94 & 0.31 & 20.51 \\
\hline Graptoleberis testudinaria (Fischer, 1848) & 0.03 & 2.94 & 0.00 & 0.00 \\
\hline Iliocryptus agilis Kurz, 1878 & 0.01 & 1.47 & 0.00 & 0.00 \\
\hline Iliocryptus sordidus (Liévin, 1848) & 0.16 & 11.76 & 0.21 & 15.38 \\
\hline Leydigia acanthocercoides (Fischer, 1854) & 0.09 & 5.88 & 0.10 & 5.13 \\
\hline Leydigia leydigi (Schoedler, 1863) & 0.04 & 2.94 & 0.05 & 2.56 \\
\hline Macrothrix laticornis (Fischer, 1848) & 0.07 & 5.88 & 0.08 & 5.13 \\
\hline Moina macrocopa (Straus, 1820) & 1.87 & 5.88 & 0.26 & 2.56 \\
\hline Moina micrura Kurz, 1874 & 99.94 & 64.71 & 164.54 & 100.00 \\
\hline Pleuroxus aduncus (Jurine, 1820) & 1.21 & 25.00 & 0.26 & 15.38 \\
\hline Pleuroxus uncinatus Baird, 1850 & 0.65 & 23.53 & 0.41 & 20.51 \\
\hline $\begin{array}{l}\text { Scapholeberis mucronata } \\
\quad \text { (O. F. Müller, 1785) }\end{array}$ & 0.09 & 5.88 & 0.13 & 7.69 \\
\hline Sida crystallina (O. F. Müller, 1776) & 0.01 & 1.47 & 0.03 & 2.56 \\
\hline Simocephalus vetulus (O. F. Müller, 1776) & 0.06 & 2.94 & 0.03 & 2.56 \\
\hline \multicolumn{5}{|l|}{ Copepoda } \\
\hline \multicolumn{5}{|l|}{ Cyclopoida } \\
\hline Acanthocyclops robustus (Sars, 1863) & 0.50 & 14.71 & 0.21 & 7.69 \\
\hline Cyclops strenuus Fischer, 1851 & 0.15 & 1.47 & 0.00 & 0.00 \\
\hline Cyclops vicinus Uljanin, 1875 & 1.72 & 4.41 & 0.00 & 0.00 \\
\hline Diacyclops bicuspidatus (Claus, 1857) & 0.04 & 1.47 & 0.00 & 0.00 \\
\hline Eucyclops serrulatus (Fischer, 1851) & 2.00 & 51.47 & 1.21 & 46.15 \\
\hline Mesocyclops leuckarti (Claus, 1857) & 0.06 & 1.47 & 0.00 & 0.00 \\
\hline Paracyclops fimbriatus (Fischer, 1853) & 0.07 & 2.94 & 0.03 & 2.56 \\
\hline Thermocyclops crassus (Fischer, 1853) & 414.53 & 79.41 & 670.82 & 100.00 \\
\hline Cyclopoid copepodit & 253.47 & 94.12 & 381.13 & 100.00 \\
\hline \multicolumn{5}{|l|}{ Calanoida } \\
\hline Eurytemora velox (Lilljeborg, 1853) & 0.13 & 5.88 & 0.00 & 0.00 \\
\hline Calanoid copepodit & 0.46 & 8.82 & 0.03 & 2.56 \\
\hline Nauplius & 156.47 & 89.71 & 204.62 & 97.44 \\
\hline Harpacticoida & 1.18 & 29.41 & 0.13 & 7.69 \\
\hline Ostracoda & 1.88 & 60.29 & 0.90 & 48.72 \\
\hline
\end{tabular}


Sampling and data analysis

Samples were collected at biweekly intervals from November 2006 to May 2008. During the winter period (between December and February), zooplankton was sampled monthly. Daily samples were always taken between 13 June and 21 July of 2007 around $4 \mathrm{~h}$. This 39-day-long period was selected according to the large individual numbers of copepods and cladocerans. Samples were taken (with a 15-1 bucket) from the open water; 501 of water was filtered through a plankton net (50 $\mu \mathrm{m}$ mesh size). The material collected was preserved in situ in $4 \%$ formaldehyde solution. In most cases, all zooplankton were identified and counted; only the samples characterised with extremely high individual numbers were split into two parts after homogenising, then one subsample was counted. Nauplii were counted in 5-ml subsamples in special counting chambers after homogenisation. For the taxonomic determination of the animals' identification keys by Gulyás and Forró (1999, 2001), Einsle (1993), Amoros (1984) and Dussart (1969) were used. Copepods and cladocerans were identified to species level; however, copepods belonging to the suborder Harpacticoida and ostracods were only counted.

Diversity patterns were analysed with the Shannon and Berger-Parker indices, diversity profiles were used to compare the diversity of assemblages at different sampling frequencies. Non-metric multidimensional scaling using the Euclidean distance was performed in order to explore temporal patterns within the 39 days and detect outliers. Data were standardised by the variance before creating the similarity matrix for the ordination. A single index (PDI) was introduced to determine the loss of information (\%) when sampling frequency is reduced. It is calculated with the formula: PDI $=$ (Maximal change within day/maximal change within the study period) $\times 100$. The denominator is constant (maximal change within 1.5 years), whereas the numerator can be altered according to the interest

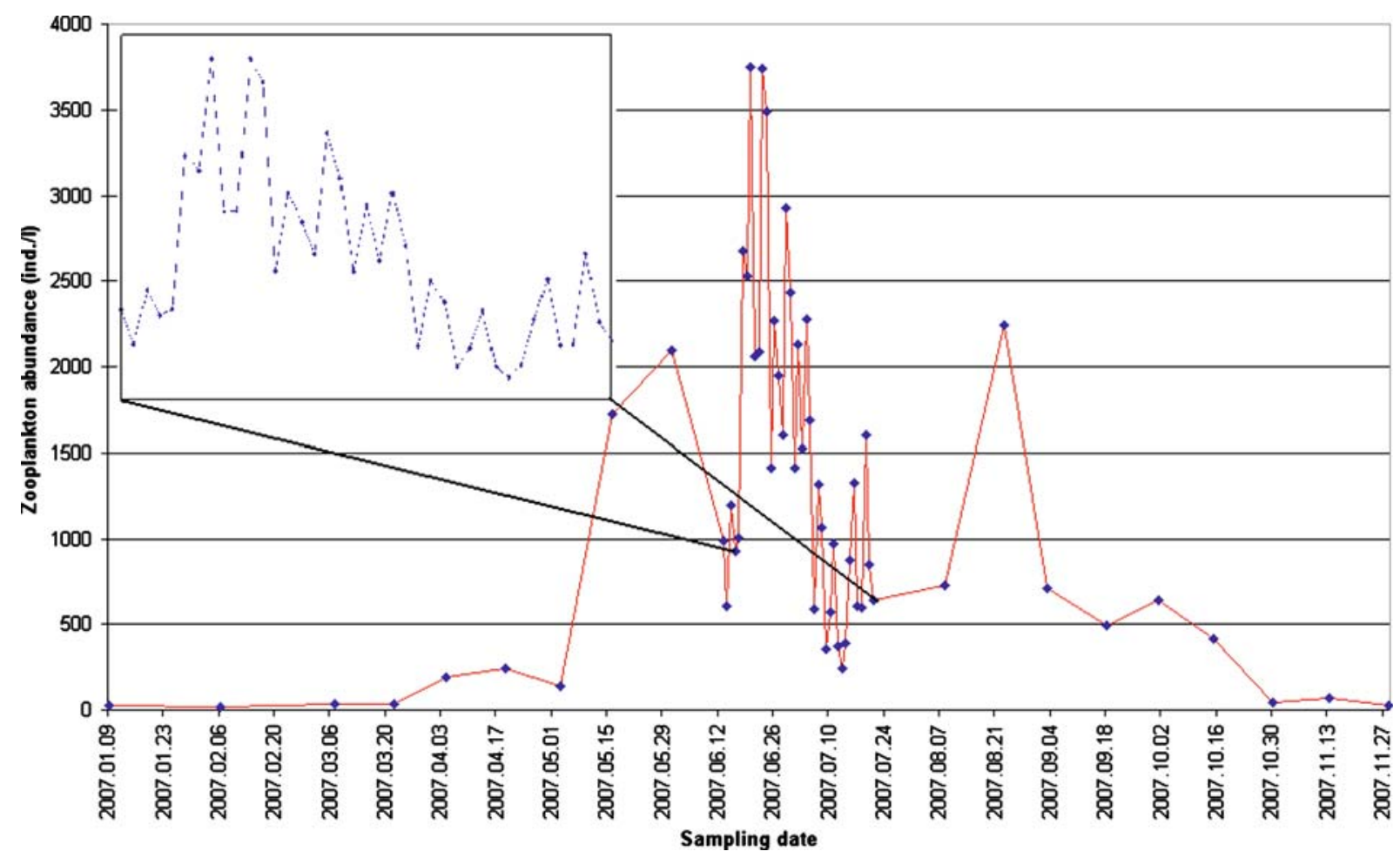

Fig. 1 Seasonal and daily changes in the abundance of crustacean plankton in the year 2007. The diagram in the upper part of the figure refers to the daily changes in zooplankton abundance between June 13 and July 21 
(1 day, 2 days, etc.). The change can refer to the change in species number, diversity or abundance of a given taxon. For determining the effect of sampling effort on the crustacean assemblage, the Du Rietz method (Du Rietz et al. 1920), the Bertalanffy model and linear regression were used. All data analyses were performed using the PAST program (Hammer et al. 2001).

\section{Results}

Community structure, temporal and diversity patterns

A total of 38 species was detected during the study period, from which 29 were cladocerans and nine were copepods (Table 1). In addition, ostracods and Harpacticoida were also recorded and included in the analysis, but they were not identified to species level. Species with the highest level of constancy included Alona rectangula, Bosmina longirostris, Diaphanosoma mongolianum, Moina micrura, Eucyclops serrulatus and Thermocyclops crassus. During the 39-day period, T. crassus, $M$. micrura and $A$. rectangula were absolutely constant. Thermocyclops crassus was the most abundant species both within the 39 days and within the whole study period. Moina micrura contributed up to $11.3 \%$ of the total zooplankton community, while B. longirostris and $T$. crassus added up to $38.3 \%$ and $46.9 \%$, respectively, of the total density.

In the year of 2007, total zooplankton abundance rapidly increased in May then remained high during the summer with notable fluctuations and decreased in early autumn (Fig. 1). Abundance peak was observed on June 20, which can be attributed to the relatively high densities of $T$. crassus. The seasonal dynamics of cladocerans and copepods showed similar patterns;

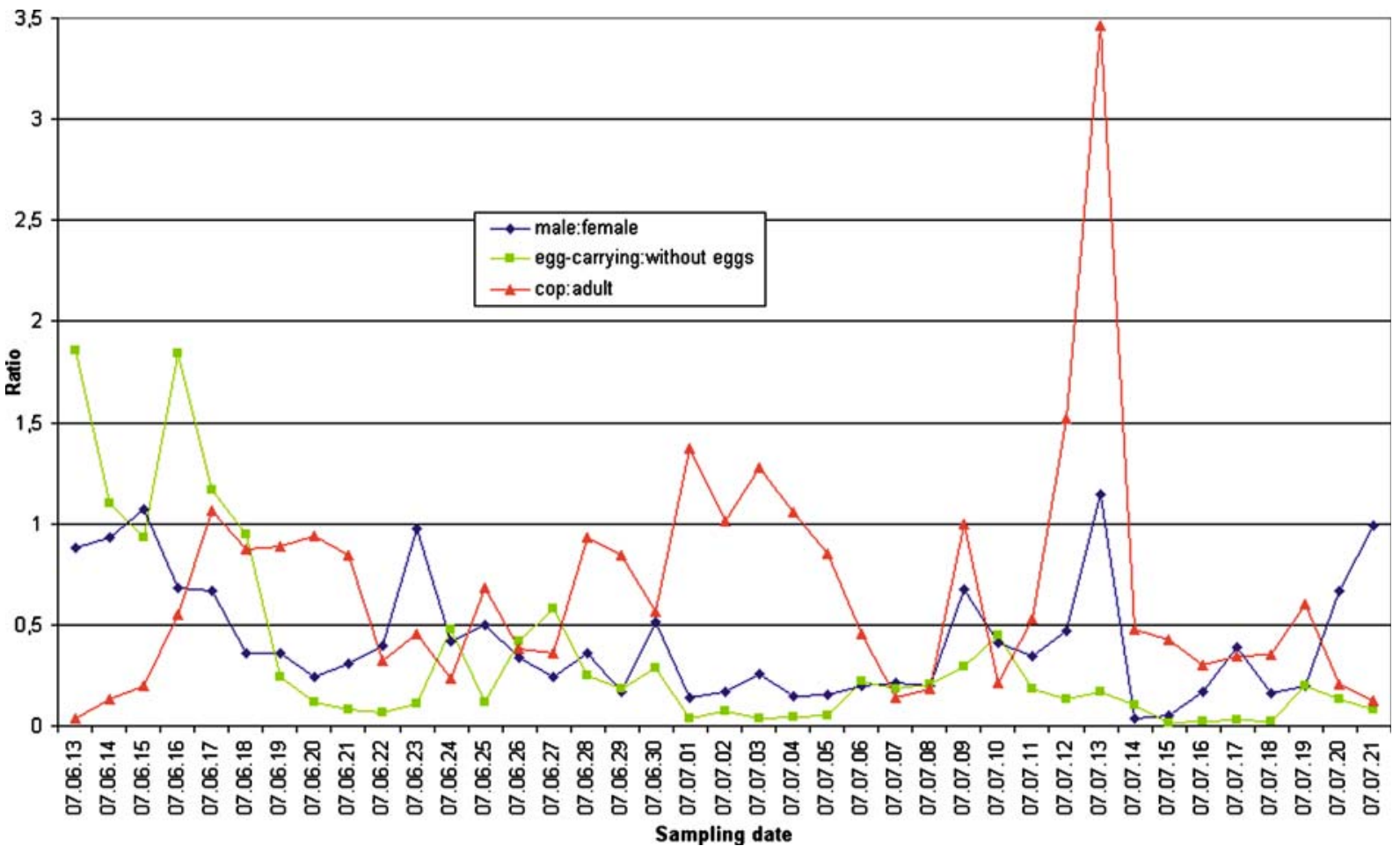

Fig. 2 The male/female, egg-carrying females/females without eggs and copepodite/adult ratios by T. crassus between June 13 and July 21 


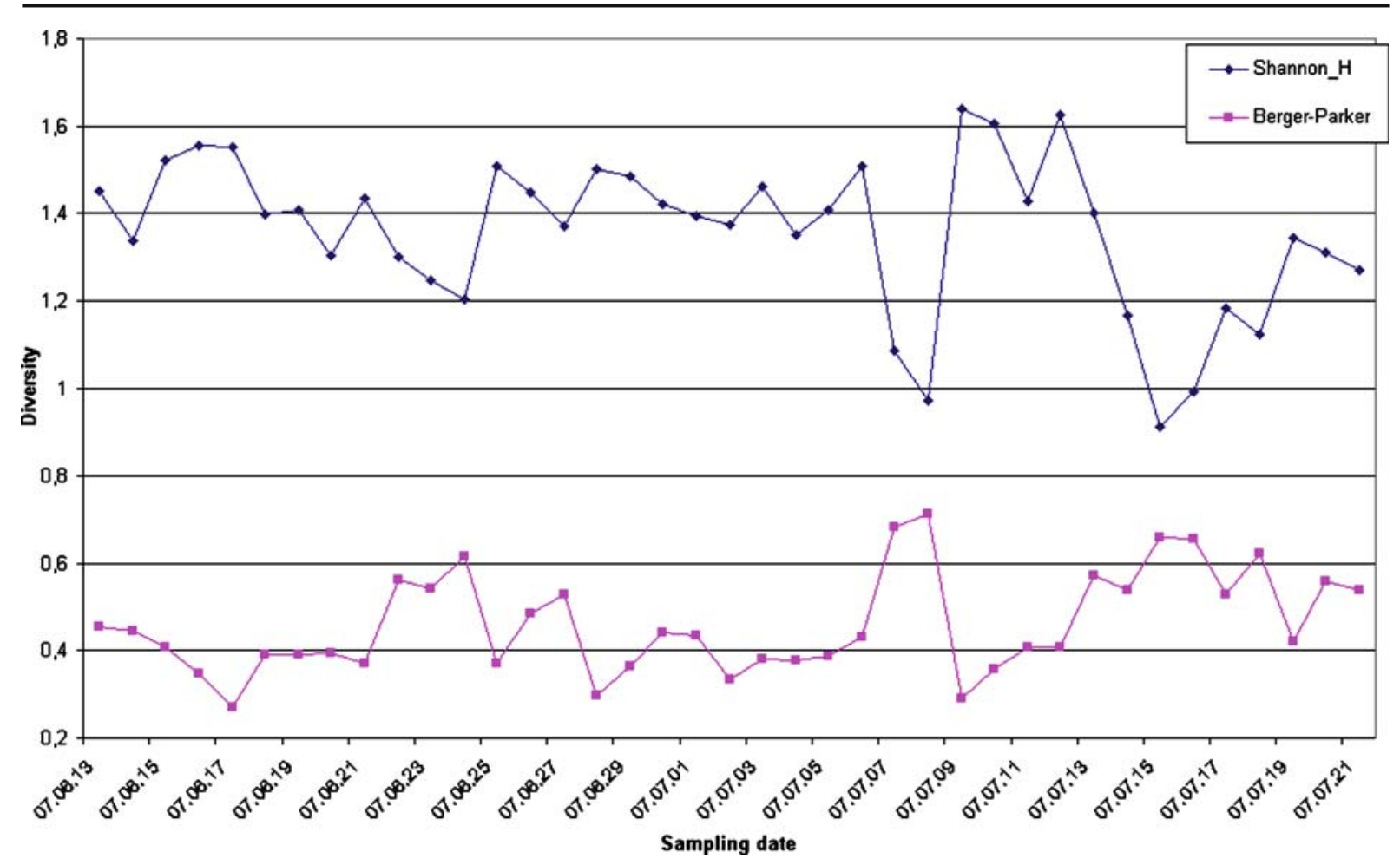

Fig. 3 The diversity patterns between June 13 and July 21 (Shannon and Berger-Parker indices)

cladocerans peaked in May while copepods in June; however, the densities of cladocerans were relatively low during the summer and copepod densities were higher in almost every case. Daily sampling was performed between 13 June and 21 July. During this term, zooplankton densities ranged from 245 to 3,746 ind./501. Much of the abundance was attributable to the population of $T$. crassus. The male/female, copepodite/adult and egg-carrying females/females without eggs ratios were also determined by $T$. crassus (Fig. 2). The male/female ratio suggests that females dominated in almost every cases. Egg-carrying individuals occurred with high frequency in mid-June, and as for the copepodite/adult ratio, mostly adult individuals dominated; copepodites peaked in the middle of July.

The diversity patterns were explored with two different diversity indices; Shannon and BergerParker diversities were calculated within the 39-day period (Fig. 3). The Berger-Parker diversity is sensitive to the dominance of the dominant species. Due to the strong dominance of
T. crassus, the Berger-Parker diversity is relatively low, suggesting that the evenness is not large. Looking at Fig. 3, the fluctuations seemed to be inverse: when the Shannon index takes the lowest values, the Berger-Parker diversity peaks and vice versa.

The similarity patterns of the 39 days are presented in Fig. 4. In order to compare the diversities of the samples taken with daily frequency (summing up the samples within the 39-day period) and the samples taken roughly once in a month (one sample), diversity profiles were constructed based on the findings of the ordination. Since there are 39 samples, from which we have to choose one, it is rewarding to select the points

Fig. 4 The ordination plot of the samples collected between June 13 and July 21 with the diversity profiles. Diversity profiles represent the diversities of the samples taken with daily frequency (summing up the samples within the 39-day period) and the samples taken roughly once in a month for days 1, 9, 31 and 37 

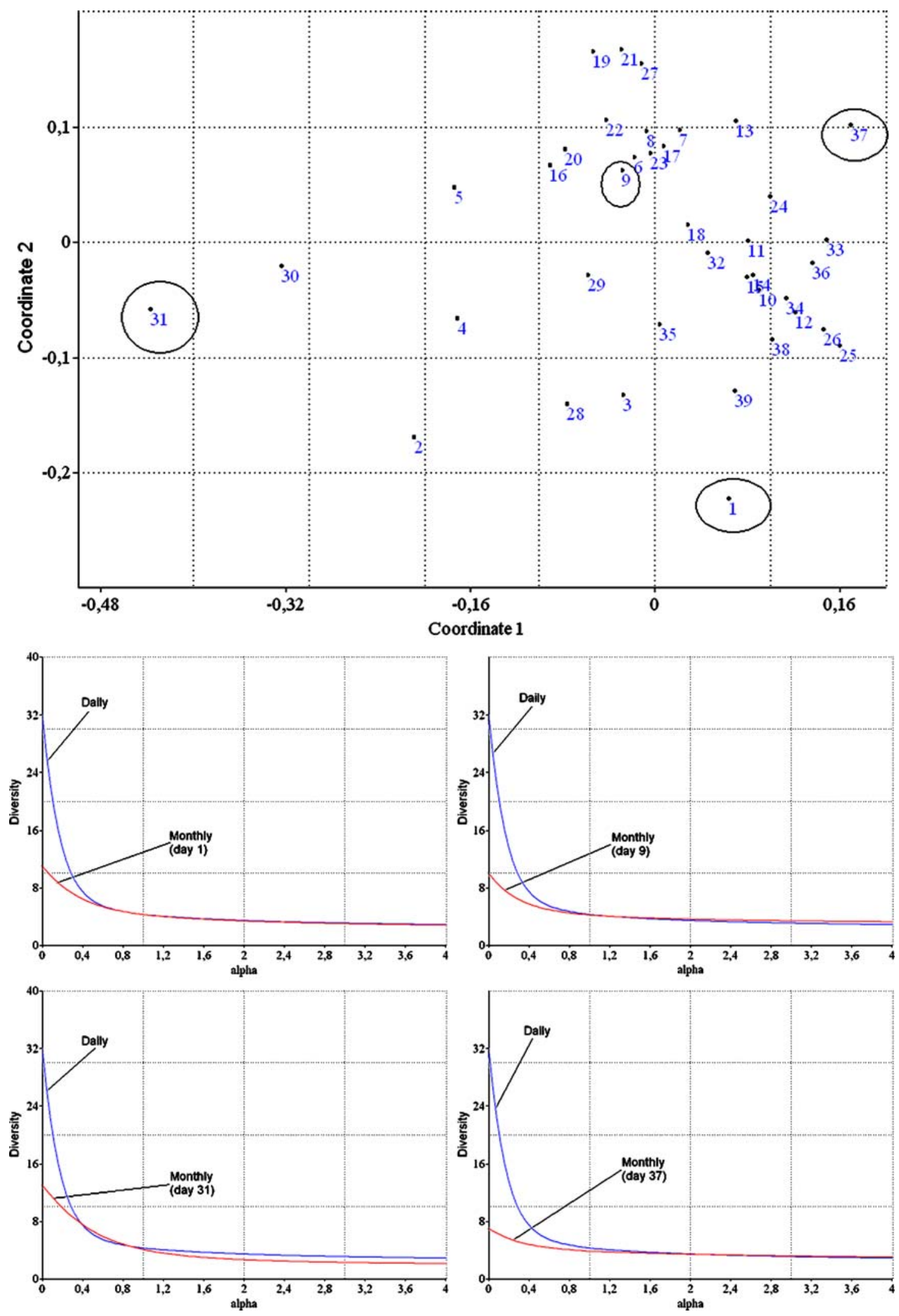
according to their ordination. Accordingly, 4 days (day 1, 9, 31 and 37) were selected from different positions for comparison with the samples collected at daily intervals. Diversity profiles suggest that samples taken on a daily basis are usually characterised with higher diversities; however, the curves are not always comparable, as they overlap (Fig. 4) with increasing distance from the intersection. The high diversities of the daily samples by minor values of alpha indicate that the species number and the number of rare species are greater here as compared to the samples taken once in a month. The other end of the scale is the measure of evenness with the Berger-Parker diversity, which implies that there is only a slight difference between the samples.

\section{Effect of sampling effort}

Originally, sample size (volume of the water taken out at the sampling site) was 501 . A total of 1,950 1 $(50 \times 39)$ of water was filtered during the 39-day period. Supposing we collect samples at 2-day intervals, we can do this in two ways depending on the first sampling date. It means 1,000 or 9501 of water, respectively, depending on the sum of samples (20 and 19 samples, respectively). At 3day intervals, there are three possible outcomes; finally, when we take only one sample within the 39-day period, there are 39 possible samples, each containing 501 of water. So altogether, a total of 780 samples can be generated. Since it is a short period, the results are not affected by seasonal dynamics, so the individual samples can be summed. When we plot the sample size (volume of water) against the number of taxa, it will form a typical accumulation curve. We managed to fit the Bertalanffy model (Fig. 5) to our data set. The results suggest that taking out 501 of water does not permit detecting several taxa. At least 2001 of water should be filtered through the plankton net in order to detect half of the species; however, 1,000 1 would be ideal (the accumulation curve becomes saturated) for detecting the majority of species (about 90\%). From another point of view, taking out 1,000 1 of water is the equivalent to a 20-day sampling period. If we measure the sample size at the logarithmic scale, linear regression can describe the relationship between sampling effort

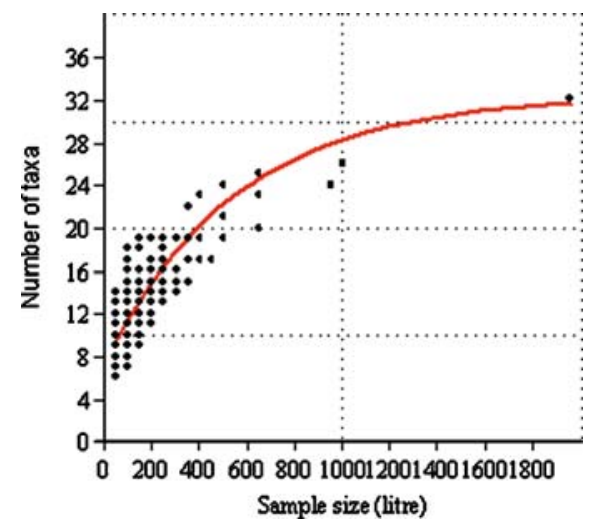

Fig. 5 Relationship between sample size and number of taxa. Bertalanffy equation: Number of taxa = $32.32\left(1-0.70797 e^{-0.001818 \text { sample size }}\right) . n=780$

and number of taxa (regression equation: number of taxa $=-12.36+12,458 \log$ sample size; $\left.r^{2}=0.82 ; n=780 ; p<0.001\right)$. Thus, instead of a logistic curve, we can describe the phenomenon in a more convenient way.

The effect of sample size can also be analysed with the rule of Du Rietz. The Du Rietz curve can be generated by plotting the five constancy levels of the species $(0-20 \%, 20-40 \%, 40-60 \%$, $60-80 \%, 80-100 \%$ ) against the number of species (Fig. 6). The rule states that, if our sample size has reached the constant minimal area of the community, the Du Rietz curve turns into a U-shape, meaning that the relative contribution of the constant and accidental species increases while the number of accessory species remains low. The curve will become asymmetrical with the highest values at lower constancy levels when the constant minimal area is not reached, as the number of absolute constant species remains low. Similarly, after going beyond the constant minimal area, the number of accidental species may increase appreciably, resulting in an asymmetrical curve with maximum values at a higher degree of constancy. Our results suggest that taking out 3001 of water is sufficient for achieving the constant minimal area (i.e. minimal sample size). Fifty liters of water (sample size used in the present study) does not represent the constant minimal area, as the number of constant species is low, whereas accidental species hit larger values. Taking out 3501 of water will lead to an asymmetrical curve 

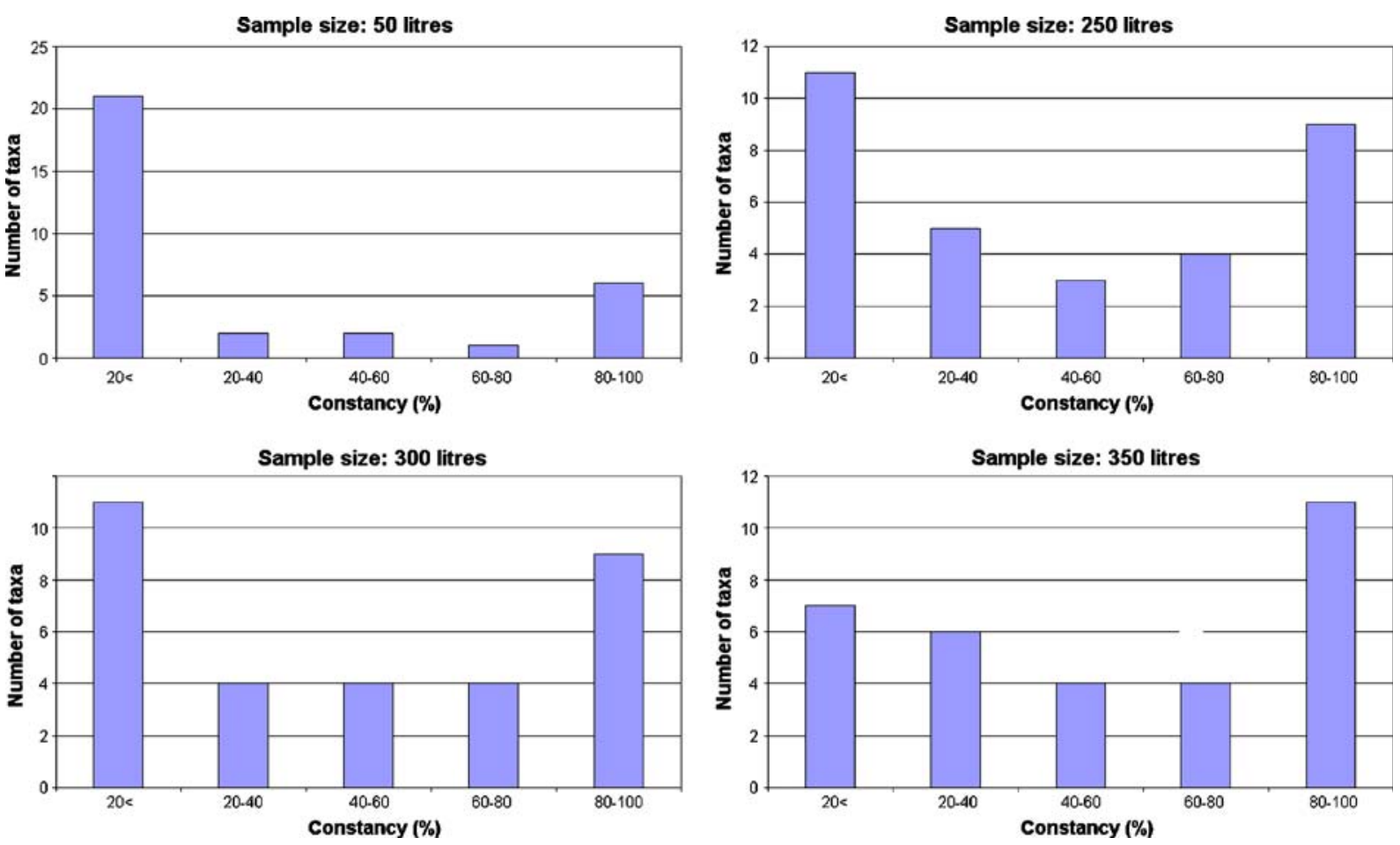

Fig. 6 Relationship between constancy levels and number of taxa in case of 50, 250, 300 and 3501 of water as sample size (Du Rietz curves)

with large numbers of constant species, meaning that the constant minimal area has been overestimated. Figure 6 shows the transitional features of the Du Rietz curves taking the applied sample size (50 l) as the starting point.

\section{Effect of sampling frequency}

A single index (PDI) was introduced to determine the loss of information (\%) when sampling frequency is reduced. The formula measures the potential loss of information depending on the sampling frequency. It was calculated for the total abundance of zooplankton, number of taxa and densities of $T$. crassus, B. longirostris and $M$. micrura, moreover, for the adult/larva ratio of copepods and for the Shannon and BergerParker indices. The loss of information refers to the loss in the estimation of the above-mentioned variables when sampling frequency is reduced. Table 2 presents the PDI index at daily sampling frequencies (based on the calculations for the 39-day period), whereas Table 3 shows the in- formation loss at biweekly sampling frequencies (based on the calculations for the whole study period, excluding samples taken on the daily basis). Results suggest that there are large differences between species, namely $T$. crassus densities change rapidly, whereas $B$. longirostris densities varied slightly ( $\sim 2 \%)$ within the 39 days. It means that the individual numbers of $T$. crassus experienced large fluctuations in the 39-day period ( $75.67 \%$ variation within 1 day as compared to the change within one and a half year of the study period). As a consequence, $75.67 \%$ potential information is lost when samples are taken at a 2-day frequency. However, looking at Table 3, B. longirostris densities showed large variation within 2 weeks $(95.94 \%)$, which is due to the fact that the population peak (15,730 ind./50 1) was not observed within the 39 days (population peak: 330 ind./50 l) but in May 2008. Thus, it is conspicuous that the PDI index indicates minor variation at daily frequency with a maximum of $2.10 \%$ variation as compared with the whole study period. Therefore, it seemed evident to present 
Table 2 The values of the PDI index (\%) at daily sampling frequencies

\begin{tabular}{|c|c|c|c|c|c|c|c|c|}
\hline $\begin{array}{l}\text { Sampling } \\
\text { frequency } \\
\text { (days) }\end{array}$ & $\begin{array}{l}\text { Total } \\
\text { abundance } \\
(\%)\end{array}$ & $\begin{array}{l}\text { Taxa } \\
(\%)\end{array}$ & $\begin{array}{l}\text { T. crassus } \\
(\%)\end{array}$ & $\begin{array}{l}\text { B. longirostris } \\
(\%)\end{array}$ & $\begin{array}{l}\text { M. micrura } \\
(\%)\end{array}$ & $\begin{array}{l}\text { Adult/larva } \\
(\%)\end{array}$ & $\begin{array}{l}\text { Shannon } \\
(\%)\end{array}$ & $\begin{array}{l}\text { Berger-Parker } \\
(\%)\end{array}$ \\
\hline 2 & 12.84 & 40.00 & 75.67 & 2.06 & 39.53 & 70.32 & 28.69 & 53.47 \\
\hline 3 & 14.42 & 40.00 & 75.67 & 2.09 & 73.02 & 86.47 & 28.69 & 53.47 \\
\hline 4 & 16.98 & 40.00 & 75.67 & 2.09 & 73.02 & 88.08 & 30.80 & 53.47 \\
\hline 5 & 17.47 & 40.00 & 77.81 & 2.09 & 73.02 & 88.76 & 30.80 & 53.47 \\
\hline 6 & 17.47 & 40.00 & 77.81 & 2.10 & 73.02 & 95.85 & 30.80 & 53.47 \\
\hline 7 & 19.42 & 40.00 & 83.19 & 2.10 & 73.02 & 98.40 & 31.36 & 53.47 \\
\hline 8 & 19.42 & 40.00 & 88.95 & 2.10 & 73.02 & 98.40 & 31.36 & 53.47 \\
\hline 9 & 19.42 & 40.00 & 88.95 & 2.10 & 73.02 & 98.40 & 31.36 & 53.47 \\
\hline 10 & 19.42 & 40.00 & 88.95 & 2.10 & 85.12 & 98.40 & 31.36 & 53.47 \\
\hline 11 & 19.42 & 40.00 & 90.58 & 2.10 & 85.12 & 98.40 & 31.36 & 53.47 \\
\hline 12 & 19.42 & 40.00 & 90.58 & 2.10 & 85.12 & 98.40 & 31.36 & 53.47 \\
\hline 13 & 19.42 & 40.00 & 90.58 & 2.10 & 86.51 & 98.40 & 31.36 & 53.47 \\
\hline 14 & 19.53 & 40.00 & 90.58 & 2.10 & 87.67 & 98.40 & 31.36 & 53.47 \\
\hline 15 & 19.53 & 40.00 & 90.58 & 2.10 & 96.98 & 98.40 & 31.36 & 53.47 \\
\hline 16 & 19.53 & 40.00 & 95.17 & 2.10 & 96.98 & 98.40 & 31.36 & 53.47 \\
\hline 17 & 20.96 & 40.00 & 95.17 & 2.10 & 96.98 & 98.40 & 31.36 & 53.47 \\
\hline 18 & 20.96 & 40.00 & 95.17 & 2.10 & 96.98 & 98.40 & 31.36 & 53.47 \\
\hline 19 & 20.96 & 40.00 & 97.68 & 2.10 & 96.98 & 98.40 & 31.36 & 53.47 \\
\hline 20 & 20.97 & 40.00 & 99.30 & 2.10 & 96.98 & 98.40 & 31.36 & 53.47 \\
\hline 21 & 21.66 & 40.00 & 99.30 & 2.10 & 96.98 & 98.40 & 31.36 & 53.47 \\
\hline 22 & 21.66 & 40.00 & 99.30 & 2.10 & 96.98 & 98.40 & 31.36 & 56.12 \\
\hline 23 & 21.66 & 40.00 & 99.30 & 2.10 & 96.98 & 98.40 & 31.36 & 56.12 \\
\hline 24 & 21.67 & 40.00 & 99.30 & 2.10 & 96.98 & 98.40 & 31.36 & 56.12 \\
\hline 25 & 21.67 & 40.00 & 99.30 & 2.10 & 96.98 & 98.40 & 31.36 & 56.12 \\
\hline 26 & 21.67 & 40.00 & 99.30 & 2.10 & 96.98 & 98.40 & 31.36 & 56.12 \\
\hline 27 & 21.67 & 40.00 & 99.30 & 2.10 & 96.98 & 98.40 & 31.36 & 56.12 \\
\hline 28 & 21.67 & 40.00 & 99.30 & 2.10 & 96.98 & 98.40 & 31.36 & 56.12 \\
\hline 29 & 21.67 & 40.00 & 99.30 & 2.10 & 96.98 & 98.40 & 31.36 & 56.12 \\
\hline 30 & 21.67 & 40.00 & 99.30 & 2.10 & 96.98 & 98.40 & 31.36 & 56.12 \\
\hline 31 & 21.67 & 40.00 & 99.30 & 2.10 & 96.98 & 98.40 & 31.36 & 56.12 \\
\hline 32 & 21.67 & 40.00 & 99.30 & 2.10 & 96.98 & 98.40 & 31.36 & 56.12 \\
\hline 33 & 21.67 & 40.00 & 99.30 & 2.10 & 96.98 & 98.40 & 31.36 & 56.12 \\
\hline 34 & 21.67 & 40.00 & 99.30 & 2.10 & 96.98 & 98.40 & 31.36 & 56.12 \\
\hline 35 & 21.67 & 40.00 & 99.30 & 2.10 & 96.98 & 98.40 & 31.36 & 56.12 \\
\hline 36 & 21.67 & 40.00 & 99.30 & 2.10 & 96.98 & 98.40 & 31.36 & 56.12 \\
\hline 37 & 21.67 & 40.00 & 99.30 & 2.10 & 96.98 & 98.40 & 31.36 & 56.12 \\
\hline 38 & 21.67 & 40.00 & 99.30 & 2.10 & 96.98 & 98.40 & 31.36 & 56.12 \\
\hline
\end{tabular}

Table 3 The values of the PDI index (\%) at biweekly sampling frequencies

\begin{tabular}{lllllllrr}
\hline $\begin{array}{l}\text { Sampling } \\
\text { frequency } \\
\text { (weeks) }\end{array}$ & $\begin{array}{l}\text { Total } \\
\text { abundance } \\
(\%)\end{array}$ & $\begin{array}{l}\text { Taxa } \\
(\%)\end{array}$ & $\begin{array}{l}\text { T. crassus } \\
(\%)\end{array}$ & $\begin{array}{l}\text { B. longirostris } \\
(\%)\end{array}$ & $\begin{array}{l}\text { M. micrura } \\
(\%)\end{array}$ & $\begin{array}{l}\text { Adult/larva } \\
(\%)\end{array}$ & $\begin{array}{l}\text { Shannon } \\
(\%)\end{array}$ & $\begin{array}{l}\text { Berger-Parker } \\
(\%)\end{array}$ \\
\hline 2 & 93.19 & 40.00 & 77.10 & 95.94 & 76.07 & 74.48 & 68.56 \\
4 & 98.96 & 55.00 & 84.61 & 99.93 & 76.07 & 95.29 & 95.35 & 100.00 \\
6 & 99.26 & 70.00 & 86.77 & 99.99 & 100.00 & 95.29 & 100.00 & 100.00 \\
8 & 99.71 & 85.00 & 96.95 & 99.99 & 100.00 & 98.44 & 100.00 & 100.00 \\
10 & 100.00 & 100.00 & 100.00 & 100.00 & 100.00 & 98.44 & 100.00 & 100.00 \\
12 & 100.00 & 100.00 & 100.00 & 100.00 & 100.00 & 98.44 & 100.00 & 100.00 \\
14 & 100.00 & 100.00 & 100.00 & 100.00 & 100.00 & 100.00 & 100.00 & 100.00 \\
\hline
\end{tabular}


the results in two different aspects (Tables 2 and 3). Similarly, the adult/larva ratio of copepods implied larger fluctuations within the 39-day term, but it is not true for the diversity indices. The Shannon and Berger-Parker indices showed large variation within 2 weeks (Table 3). Considering all variables, 14 weeks ( $\sim 3$ months) proved to be enough to achieve the $100 \%$ variation within the whole study period. However, the densities of T. crassus, M. micrura and the adult/larva ratio of copepods displayed major variations (above 90\%) within 2 weeks (Table 2). The variations in the number of taxa were constant $(40 \%)$ within the 39 days and reached the $100 \%$ limit at 10 weeks. Total zooplankton abundance varied moderately within the 39 days but showed major variation $(93.19 \%)$ within 2 weeks in the whole study period, which can be originated in the population peak of B. longirostris.

\section{Discussion}

Our results pointed out that sampling effort and sampling frequency can have a significant impact on the monitoring of the planktonic crustacean assemblage at least within the framework of the present case study.

Diversity patterns proved to be one useful tool for describing the zooplankton community structure. The inverse fluctuations of the Shannon and Berger-Parker indices can be attributed to the sensibility of measures. Berger-Parker index is relatively sensitive to the evenness, whereas the Shannon index considers the species number rather important. When the Berger-Parker index takes large values, the abundance of the dominant species ( $T$. crassus) is low indicating relatively large evenness; however, it does not mean large species number definitely. The examined water body was not species-poor but it was strongly dominated by one species (T. crassus); thus, calculating the Berger-Parker index seemed to be relevant. Diversity profiles indicated that samples taken on a daily basis can be characterised by higher diversities, particularly regarding species richness. However, the results are not always comparable due to the overlapping curves. This suggests that, as for the evenness, there are only minor differences between samples taken at daily frequency and those of once in a month.

The effect of sampling effort was tested with two different methods. The minimal sample size resulted in 1,000 and 3001 of water, respectively. This sample size is beyond those applied in the studies of riverine plankton: 101 (Illyová 2006), 201 (De Ruyter Van Steveninck et al. 1990), 251 (Vranovsky 1991), 301 (Saunders and Lewis 1989), 401 (Reckendorfer et al. 1999), 501 (Gulyás 1995), 601 (Ietswaart et al. 1999), 1001 (Gulyás 1994; Maria-Heleni et al. 2000) and 2001 (V.Balogh et al. 1994; Bothár 1988; Bothár and Kiss 1990). Obviously, taking 1,000 1 of water would mean an enormous effort, and this should not be the desired goal. We have seen that taking out such a large volume of water will represent about $90 \%$ of the species; however, we do not need to detect $90 \%$ of the species in one sample definitely. The results are based on 39 days, which is not capable of detecting seasonal patterns. Taking out 501 of water in winter is not the equivalent of a 50-1 plankton sample taken in summer. The latter would contain far more species because seasonality influences taxa composition. The lowest number of taxa (one species) was detected in the beginning of March, whereas the highest number was 21 taxa in May. During the 39-day period, the number of taxa ranged between six and 14 . The seasonal changes in zooplankton species composition are well-documented in rivers as well (Kim and Joo 2000; Kobayashi et al. 1998; MariaHeleni et al. 2000; Illyová 2006; Tubbing et al. 1994). Thus, many species could not be registered in the present case study because of the shortterm observation. This being the case, our results should be handled watchfully.

The Du Rietz rule was tested exactly only for homogeneous plant associations with low species number. In heterogeneous associations with high species richness, the Du Rietz curve can be skewed (Balogh 1953). According to the present work, the Du Rietz curve has taken the U-shape, more or less proving that it can be used for such communities. The rule can only be applied for taxa with minor variations in size within a definite order of magnitude. This assumption is fulfiled in case of planktonic crustaceans. Our results suggested that some 3001 of water represents the 
constant minimal area (i.e. minimal sample size) of the crustacean plankton in the Sport-sziget side arm. However, we should not forget that the size of the minimal area is subject to seasonal and regional variations (Kronberg 1987).

Generally, seasonal dynamics of riverine zooplankton have been discussed on the basis of samples collected at biweekly (Kim and Joo 2000; Maria-Heleni et al. 2000; Reckendorfer et al. 1999) or weekly intervals (Bothár 1988; Bothár and Kiss 1990; V.-Balogh et al. 1994). Bothár (1996) performed zooplankton investigations in the river Danube on the daily basis and pointed out that no regular quantitative change or fluctuation in zooplankton abundance can be observed, although phytoplankton and water chemical data showed regular daily patterns. Copepods showed 2-3-day periodicities, which was attributable to the structural changes of different developmental stages. The author considered the weekly sampling strategy as an adequate tool to get a clear picture of the species composition and quantitative changes of zooplankton in the river Danube. Our results (PDI index) indicate that abundances may experience notable fluctuations even within 1 week, as do diversities and adult/larva ratios. According to the findings within the 1.5-year study period, samples taken at biweekly frequencies are not always sufficient (PDI for total abundance is 93\% within 2 weeks). This is partly due to the relatively short generation time of cladocerans. The present study is only confined to planktonic crustaceans; however, rotifers are characterised with shorter generation times (Akopian et al. 2002; Lair 2006) and they are often the dominant component of riverine zooplankton (Gulyás 1995-Danube River; Burger et al. 2002Waikato River; Kim and Joo 2000-Nakdong River; Maria-Heleni et al. 2000-Aliakmon River; Saunders and Lewis 1988-Apure River; Saunders and Lewis 1989-Orinoco River; Van Dijk and Van Zanten 1995-Rhine River; Thorp et al. 1994-Ohio River). Therefore, additional research is needed when sampling strategies of zooplankton can be evaluated.

In summary, we demonstrated within the framework of a case study in the river Danube that the quantitative and qualitative compositions of the zooplankton samples are strongly influenced by sampling effort and sampling frequency. The findings should be handled watchfully, but they can serve as a basis for future research.

\section{References}

Akopian, M., Garnier, J., \& Pourriot, R. (2002). Cinétique du zooplancton dans un continuum aquatique: De la Marne et son réservoir a l' estuaire de la Seine. Comptes Rendus Biologies, 325, 807-818. doi:10.1016/S1631-0691(02)01483-X.

Amoros, C. (1984). Crustacés cladocères, Introduction pratique a la systématique des organismes des eaux continentales francaises. Bulletin Mensuel de la Societe Linneenne de Lyon, 53, 1-63.

Balogh, J. (1953). A zoocönológia alapjai-Grundzüge der Zoocönologie. Budapest: Akadémiai Kiadó.

Bollens, S. M., \& Frost, B. W. (1991). Diel vertical migration in zooplankton: Rapid individual responses to predators. Journal of Plankton Research, 13, 13591365. doi:10.1093/plankt/13.6.1359.

Bothár, A. (1987). Produktionsschätzung von Acanthocyclops robustus (G. O. Sars) in der Donau (26, pp. 339343). Arbeitstagung der IAD, Passau/Deutschland, Wissenschaftliche Kurzreferate.

Bothár, A. (1988). Results of long-term zooplankton investigations in the River Danube, Hungary. Verhandlung Internationale Vereinigung Limnologie, 23, 1340-1343.

Bothár, A. (1996). Die lang-und kurzfristigen Änderungen in der Gestaltung des Zooplanktons (Cladocera, Copepoda) der Donau - Probeentnahmestrategien (31, pp. 201-206). Arbeitstagung der IAD, Baja/Ungarn, Wissenschaftliche Referate.

Bothár, A., \& Kiss, K. T. (1990). Phytoplankton and zooplankton (Cladocera, Copepoda) relationship in the eutrophicated river Danube (Danubialia Hungarica, CXI). Hydrobiologia, 191, 165-171. doi:10.1007/BF00026050.

Burger, D. F., Hogg, I. D., \& Green, J. D. (2002). Distribution and abundance of zooplankton in the Waikato River, New Zealand. Hydrobiologia, 479, 3138. doi:10.1023/A:1021064111587.

Cao, Y., Williams, D. D., \& Williams, N. E. (1998). How important are rare species in aquatic community ecology and bioassessment? Limnology and Oceanography, 43, 1403-1409.

Cao, Y., Larsen, D. P., Hughes, R. M., Angermeier, P. L., \& Patton, T. M. (2002a). Sampling effort affects multivariate comparisons of stream assemblages. Journal of the North American Benthological Society, 21, 701714. doi: $10.2307 / 1468440$.

Cao, Y., Williams, D. D., \& Larsen, D. P. (2002b). Comparison of ecological communities: The problem of sample representativeness. Ecological Monographs, 72, 41-56. 
Cuker, B. E., \& Watson, M. A. (2002). Diel vertical migration of zooplankton in contrasting habitats of the Chesapeake Bay. Estuaries, 25, 296-307. doi:10.1007/ BF02691317.

Cushing, D. H. (1951). The vertical migration of planktonic Crustacea. Biological Reviews of the Cambridge Philosophical Society, 26, 158-192. doi:10.1111/j.1469185X.1951.tb00645.x.

DePatta Pillar, V. (1998). Sampling sufficiency in ecological surveys. Abstracta Botanica, 22, 37-48.

De Ruyter Van Steveninck, E. D., Van Zanten, B., \& Admiraal, W. (1990). Phases in the development of riverine plankton: Examples from the rivers Rhine and Meuse. Hydrological Bulletin, 24, 47-55. doi:10.1007/BF02256748.

Du Rietz, G. E., Fries, T. C. E., Oswald, H., \& Tengwall, Y. A. (1920). Gesetze der Konstitution natürlicher Pflanzengesellschaften. Flora Fauna, 7, 1-47.

Dussart, B. (1969). Les Copepodes des Eaux Continentales II: Cyclopoides et Biologie. Ed. N. Boubee \& Cie, Paris.

Efron, B. (1979). Bootsrap methods: Another look at the jackknife. Annals of Statistics, 7, 1-25. doi:10.1214/ aos/1176344552.

Efron, B., \& Tibshirani, R. (1993). An introduction to the bootsrap. London: Chapman \& Hall.

Einsle, U. (1993). Crustacea, copepoda: Calanoida und cyclopoida. In J. Schwoerbel \& P. Zwick (Ed.), Süsswasserfauna von Mitteleuropa, Bd. 8, Heft 4, Teil 1 (pp. 1-208). Stuttgart: Gustav Fischer Verlag.

Ferrari, I., Cantarelli, M. T., Mazzocchi, M. G., \& Tosi, L. (1985). Analysis of a 24-hour cycle of zooplankton sampling in a lagoon of the Po River Delta. Journal of Plankton Research, 7, 849-865. doi:10.1093/plankt/ 7.6.849.

Gauch, H. G. (1982). Multivariate analysis in community ecology. Cambridge: Cambridge University Press.

Gulyás, P. (1987). Tägliche Zooplankton-Untersuchungen im Donau-Nebenarm bei Ásványráró im Sommer 1985 (26, pp. 123-126.) Arbeitstagung der IAD, Passau/Deutschland, Wissenschaftliche Kurzreferate.

Gulyás, P. (1994). Studies on the Rotatorian and Crustacean plankton in the Hungarian section of the Danube between 1848,4 and 1659,0 riv. $\mathrm{km}$. In R. Kinzelbach (Ed.), Biologie der Donau (pp. 49-61). Stuttgart: Gustav Fischer Verlag.

Gulyás, P. (1995). Rotatoria and Crustacea plankton of the River Danube between Bratislava and Budapest. Miscellanea Zoologica Hungarica, 10, 7-19.

Gulyás, P., \& Forró, L. (1999). Az ágascsápú rákok (Cladocera) kishatározója, 2. bövített kiadás. Vízi Természet- és Környezetvédelem, 9. kötet. Budapest: Környezetgazdálkodási Intézet.

Gulyás, P., \& Forró, L. (2001). Az evezólábú rákok (Calanoida és Cyclopoida) alrendjeinek kishatározója, 2. bövített kiadás. Vízi Természet-és Környezetvédelem, 14. kötet. Budapest: Környezetgazdálkodási Intézet.

Hammer, O., Harper, D. A. T., \& Ryan, P. D. (2001). PAST: Paleontological Statistics software package for education and data analysis. Palaeontologia Electronica, 4(1), 1-9.
Ietswaart, T. H., Breebaart, L., Van Zanten, B., \& Bijkerk, R. (1999). Plankton dynamics in the river Rhine during downstream transport as influenced by biotic interactions and hydrological conditions. Hydrobiologia, 410, 1-10. doi:10.1023/A:1003801110365.

Illyová, M. (2006). Zooplankton of two arms in the Morava River floodplain in Slovakia. Biologia, 61, 531-539. doi:10.2478/s11756-006-0087-8.

Kim, H. W., \& Joo, G. J. (2000). The longitudinal distribution and community dynamics of zooplankton in a regulated large river: A case study of the Nakdong River (Korea). Hydrobiologia, 438, 171-184. doi:10.1023/ A:1004185216043.

Kobayashi, T., Shiel, R. J., Gibbs, P., \& Dixon, P. I. (1998). Freshwater zooplankton in the HawkesburyNepean River: Comparison of community structure with other rivers. Hydrobiologia, 377, 133-145. doi:10.1023/A:1003240511366.

Kronberg, I. (1987). Accuracy of species and abundance minimal areas determined by similarity area curves. Marine Biology (Berlin), 96, 555-561. doi:10.1007/ BF00397974.

Lair, N. (2006). A review of regulation mechanisms of metazoan plankton in riverine ecosystems: Aquatic habitat versus biota. River Research and Applications, 22, 567-593. doi:10.1002/rra.923.

Lampert, W. (1989). The adaptive significance of diel vertical migration of zooplankton. Functional Ecology, 3, 21-27. doi:10.2307/2389671.

Marchant, R. (1999). How important are rare species in aquatic ecology and bioassessment? A comment to conclusions of Cao et al. 1999. Limnology and Oceanography, 44, 1840-1841.

Maria-Heleni, Z., Michaloudi, E., Bobori, D. C., \& Mourelatos, S. (2000). Zooplankton abundance in the Aliakmon River, Greece. Belgian Journal of Zoology, 130, 29-33.

Mavuti, K. M. (1994). Durations of development and production estimates by two crustacean zooplankton species Thermocyclops oblongatus Sars (Copepoda) and Diaphanosoma excisum Sars (Cladocera) in Lake Naivasha, Kenya. Hydrobiologia, 272, 185-200. doi:10.1007/BF00006520.

Naidenow, W. (1998). Das Zooplankton der Donau. In E. Kusel-Fetzmann, W. Naidenow, \& B. Russev (Eds.), Plankton und Benthos der Donau, Ergebnisse der Donau-Forschung, Band 4 (pp. 163-248). Wien: Internationale Arbeitsgemeinschaft Donauforschung.

Reckendorfer, W., Keckeis, H., Winkler, G., \& Schiemer, F. (1999). Zooplankton abundance in the River Danube, Austria: The significance of inshore retention. Freshwater Biology, 41, 583-591. doi:10.1046/ j.1365-2427.1999.00412.x.

Saunders, J. F., \& Lewis, W. M. (1988). Zooplankton abundance and transport in a tropical whitewater river. Hydrobiologia, 162, 147-155. doi:10.1007/ BF00014537.

Saunders, J. F., \& Lewis, W. M. (1989). Zooplankton abundance in the lower Orinoco River, Venezuela. Limnology and Oceanography, 34, 397-409. 
Schmera, D., \& Erós, T. (2006). Estimating sample representativeness in a survey of stream caddisfly fauna. Annales de Limnologie - International. Journal of Limnology, 42, 181-187.

Schmera, D., \& Erős, T. (2008). A mintavételi erőfeszítés hatása a mintareprezentativitásra. Acta Biologica Debrecina Supplementum Oecologica Hungarica, 18, 209-213.

Thorp, J. H., Black, A. R., Haag, K. H., \& Wehr, J. D. (1994). Zooplankton assemblages in the Ohio River: Seasonal, tributary, and navigation dam effects. Canadian Journal of Fisheries and Aquatic Sciences, 51, 1634-1643. doi:10.1139/f94-164.

Tubbing, D. G. M. J., Admiraal, W., Backhaus, D., Friedrich, G., Van Steveninck, E. D. D., Muller, D., et al. (1994). Results of an international plankton investigation on the River Rhine. Water Science and Technology, 29, 9-19.
Van Dijk, G. M., \& Van Zanten, B. (1995). Seasonal changes in zooplankton abundance in the lower Rhine during 1987-1991. Hydrobiologia, 304, 29-38. doi:10.1007/BF02530701.

V.-Balogh, K., Bothár, A., Kiss, K. T., \& Vörös, L. (1994). Bacterio-, phyto- and zooplankton of the River Danube (Hungary). Verhandlung Internationale Vereinigung Limnologie, 25, 1692-1694.

Vranovsky, M. (1991). Zooplankton of a Danube side arm under regulated ichthyocoenosis conditions. Verhandlung Internationale Vereinigung Limnologie, 24, 2505-2508.

Zagami, G., Badalamenti, F., Guglielmo, L., \& Manganaro, A. (1996). Short-term variations of the zooplankton community near the straits of Messina (North-eastern Sicily): Relationships with the hydrodynamic regime. Estuarine, Coastal and Shelf Science, 42, 667-681. doi:10.1006/ecss.1996.0043. 